\title{
Homocysteine, folate, vitamin B12, and cardiovascular risk in Indians, Malays, and Chinese in Singapore
}

\author{
Kenneth Hughes, Choon-Nam Ong
}

\begin{abstract}
Objective-To examine the hypothesis that the higher rates of coronary heart disease (CHD) in Indians (South Asians) compared with Malays and Chinese is partly attributable to differences in blood concentrations of homocysteine, and related blood concentrations of folate and vitamin B12.
\end{abstract}

Design-Cross sectional study of the general population.

Setting-Singapore.

Participants-Random sample of 726 fasting subjects aged 30 to 69 years.

Main results-Mean plasma total homocysteine concentrations did not show significant ethnic differences; values were Indians (men 16.2 and women $11.5 \mu \mathrm{mol} /$ 1), Malays (men 15.0 and women 12.5 $\mu \mathrm{mol} / \mathrm{l}$ ), and Chinese (men 15.3 and women $12.2 \mu \mathrm{mol} / 1)$. Similarly, the proportions with high plasma homocysteine (>14.0 $\mu \mathrm{mol} / \mathrm{l})$ showed no important ethnic differences being, Indians (men 60.0 and women $21.9 \%$ ), Malays (men 53.9 and women $37.8 \%$ ), and Chinese (men 56.6 and women $30.6 \%$ ). Mean plasma folate concentrations were lower in Indians (men 8.7 and women $10.9 \mathrm{nmol} / \mathrm{l}$ ) and Malays (men 8.5 and women $10.8 \mathrm{nmol} / \mathrm{l}$ ), than Chinese (men 9.7 and women 13.8 nmol/1). Similarly, the proportions with low plasma folate $(<6.8 \mathrm{nmol} / \mathrm{l})$ were higher in Indians (men 44.9 and women $36.6 \%$ ) and Malays (men 45.3 and women $24.5 \%$ ) than Chinese (men 31.4 and women $12.6 \%$ ). Mean plasma vitamin B12 concentrations were lowest in Indians (men 352.5 and women $350.7 \mathrm{pmol} / 1$ ), then Chinese (men 371.1 and women 373.7 pmol/1), and then Malays (men 430.5 and women $486.0 \mathrm{pmol} / 1)$.

Conclusion-While there were ethnic differences for plasma folate and vitamin B12 (in particular lower levels in Indians), there was no evidence that homocysteine plays any part in the differential ethnic risk from CHD in Singapore and in particular the increased susceptibility of Indians to the disease.

(F Epidemiol Community Health 2000;54:31-34)

Indians or South Asians (that is, persons from the Indian subcontinent) have been found in a number of countries to be particularly susceptible to coronary heart disease (CHD). ${ }^{1}$ Singapore has a population of 3.3 million people composed of Chinese $76 \%$, Malays $14 \%$, Indians $7 \%$, and Others 3\%. Of the Indians, $80 \%$ originate from Southern India (Tamil Nadu and Kerala) and Sri Lanka.

In Singapore, Indians have more CHD (but not more cerebrovascular disease) than Malays and Chinese, with Malays having more CHD than Chinese. ${ }^{2}$ The greater susceptibility of Indians to $\mathrm{CHD}$ is not explained by cigarette smoking, hypertension and hypercholesterolaemia. ${ }^{3}$ Compared with $\mathrm{Ma}-$ lays and Chinese, Indians have more abdominal obesity and insulin resistance, and some components of Syndrome X (lower high density lipoprotein cholesterol, more glucose intolerance, and higher plasminogen activator inhibitor type 1), which partly explains their increased susceptibility to CHD. ${ }^{4}$ Also, Indians have higher levels of lipoprotein(a), ${ }^{4}$ and lower levels of vitamin $\mathrm{C}$ and selenium (both anti-oxidants), ${ }^{5}$ which could increase their risk of CHD. However, other mechanisms may exist.

Homocysteine is a sulphur containing amino acid formed during the metabolism of methionine, an essential amino acid derived from dietary protein. Epidemiological studies indicate that hyperhomocysteinaemia is a risk factor for atherothrombotic disease, though the molecular mechanism is not clear. ${ }^{6}$ Homocysteine is metabolised with folate as a co-substrate and vitamin $\mathrm{B} 12$ as a co-factor and low levels of these vitamins causes hyperhomocysteinaemia. ${ }^{6}$ A study found an association between low serum folate and cardiovascular disease mortality, ${ }^{7}$ and there may be benefits from increasing folate intake. ${ }^{8}$ This article examines plasma homocysteine, folate, and vitamin B12, among the three main ethnic groups in Singapore.

\section{Methods}

SAMPLE

The data are from the National University of Singapore Heart Study, which was a cross sectional survey of a random sample of persons aged 30 to 69 years from the general population of Singapore. The sampling has been described in detail. ${ }^{4}$ There was a response rate of $71.2 \%$. Of the 961 responders, 726 persons (randomly selected) had measurements of plasma homocysteine, folate, and vitamin B12.

PROCEDURES

Morning clinics were held from June 1993 to December 1995 with the two genders and three ethnic groups seen concurrently. The 
Table 1 Pearson partial correlation coefficients ( $p$ values), adjusted for age, between plasma homocysteine, folate, and vitamin B12, for 369 men and 357 women aged 30 to 69 years

\begin{tabular}{lll}
\hline & Homocysteine & Vitamin B12 \\
\hline $\begin{array}{ll}\text { Homocysteine } \\
\text { Men }\end{array}$ & & $-0.02(0.73)$ \\
$\quad$ Women & & $-0.01(0.93)$ \\
Folate & & \\
Men & $-0.14(<0.01)$ & $0.30(<0.01)$ \\
Women & $-0.11(0.04)$ & $0.24(<0.01)$ \\
\hline
\end{tabular}

subjects were asked to fast from 2100 the previous evening.

Venous blood specimens were taken with the subject in a sitting position using venoject vacuum containers with minimum venous stasis. Within 30 minutes, the blood was spun and plasma separated. Specimens were stored at $-20^{\circ} \mathrm{C}$ with all measurements made at the end of the project. Measurement of plasma total homocysteine was by high performance liquid chromatography (HPLC), ${ }^{9}$ and of plasma folate and vitamin B12 by radioimmunoassay. ${ }^{10}$ The reproducibility (precision) of the measurements for all parameters were above $95 \%$. The coefficients of variation $(n=4)$ for within and between assays were, homocysteine $1.3 \%$ and $5.1 \%$, folate $2.7 \%$ and $4.5 \%$, and vitamin $\mathrm{B} 12$ $3.3 \%$ and $5.0 \%$. High concentrations of plasma homocysteine were taken as $>14.0 \mu \mathrm{mol} / 1,{ }^{6}{ }^{11}{ }^{12}$ and low concentrations of plasma folate as $<6.8 \mathrm{nmol} / \mathrm{l}^{13}$

ANALYSIS

The distributions of homocysteine, folate and vitamin B12 were near normal with just slight skewing to the right, and hence there was no log transformation and arithmetic means have been calculated. Though the mean ages were similar by gender and ethnic group, there was age adjustment. Pearson product moment partial correlation coefficients, adjusted for age, were calculated on SPSS. Age adjustment was performed for means by analysis of covariance
KEY POINTS

- In Singapore, coronary heart disease (CHD) is highest in Indians, then Malays, and then Chinese.

- Plasma folate is lower in Indians and Malays than Chinese and plasma vitamin B12 is lowest in Indians. Lower antioxidant activity in Indians may play a part in their higher susceptibility to CHD.

- There are no ethnic differences for plasma total homocysteine.

- Hyperhomocysteinaemia seems to play no part in ethnic differences for CHD in Singapore and in particular the increased susceptibility of Indians to the disease.

using the GLM Procedure of SAS and for prevalences by direct standardisation to the total sample population with significance testing by the $\mathrm{Z}$ test. All significance testing was two tailed.

\section{Results}

Table 1 shows in both genders, that there were moderate direct correlations between folate and vitamin B12, slight/moderate inverse correlations between homocysteine and folate, but no correlations between homocysteine and vitamin B12.

Table 2 shows that mean plasma homocysteine concentrations were higher in men than women for all three ethnic groups. However, homocysteine showed no significant ethnic differences, with Indians having slightly higher levels in men and slightly lower levels in women. Table 3 further shows that the only significant difference for high homocysteine was that Malay women had a higher proportion than Indian women by $15.9 \%$.

Mean plasma folate concentrations were lower in men than women for all three ethnic groups (table 2). Concentrations were lower in

Table 2 Means (95\% confidence intervals), age adjusted by analysis of covariance, of plasma homocysteine, folate, and vitamin B12, for Indians (I), Malays (M), and Chinese (C), by gender, for age group 30 to 69 years

\begin{tabular}{|c|c|c|c|c|c|c|}
\hline & \multirow{2}{*}{$\begin{array}{l}\text { Indians }(\text { men }=129, \\
\text { women }=119)\end{array}$} & \multirow{2}{*}{$\begin{array}{l}\text { Malays (men =104, } \\
\text { women =106) }\end{array}$} & \multirow{2}{*}{$\begin{array}{l}\text { Chinese (men =136, } \\
\text { women }=132 \text { ) }\end{array}$} & \multicolumn{3}{|c|}{ Significance, $p$ value } \\
\hline & & & & $I v M$ & $I v C$ & $M v C$ \\
\hline \multicolumn{7}{|c|}{ Homocysteine $(\mu \mathrm{mol} / \mathrm{l})$} \\
\hline Men & $16.2(15.1,17.2)$ & $15.0(13.8,16.1)$ & $15.3(14.3,16.3)$ & 0.13 & 0.23 & 0.99 \\
\hline Women & $11.5(10.5,12.3)$ & $12.5(11.5,13.5)$ & $12.2(11.3,13.1)$ & 0.17 & 0.31 & 0.68 \\
\hline \multicolumn{7}{|c|}{ Folate $(\mathrm{nmol} / \mathrm{l})$} \\
\hline Men & $8.7(7.8,9.6)$ & $8.5(7.5,9.5)$ & $9.7(8.8,10.6)$ & 1.00 & 0.39 & 0.21 \\
\hline Women & $10.9(9.2,12.7)$ & $10.8(8.9,12.6)$ & $13.8(12.1,15.4)$ & 1.00 & 0.07 & 0.06 \\
\hline \multicolumn{7}{|c|}{ Vitamin B12 (pmol/1) } \\
\hline Men & $352.5(320.5,384.4)$ & $430.5(395.0,460.0)$ & $371.1(340.0,402.3)$ & $<0.01$ & 0.41 & 0.01 \\
\hline Women & $350.7(318.7,385.0)$ & $486.0(449.8,522.2)$ & $373.7(341.2,406.1)$ & $<0.01$ & 0.34 & $<0.01$ \\
\hline
\end{tabular}

Table 3 Prevalence rates \% (95\% confidence intervals), age adjusted by direct standardisation to the total sample, of high plasma homocysteine (>14.0 $\mu \mathrm{mol} / \mathrm{l})$ and low plasma folate $(<6.8 \mathrm{nmol} / \mathrm{l})$, for Indians (I), Malays (M), and Chinese (C), by gender, for age group 30 to 69 years

\begin{tabular}{|c|c|c|c|c|c|c|}
\hline & \multirow{2}{*}{$\begin{array}{l}\text { Indians }(\text { men }=129, \\
\text { women }=119)\end{array}$} & \multirow{2}{*}{$\begin{array}{l}\text { Malays (men }=104, \\
\text { women }=106)\end{array}$} & \multirow{2}{*}{$\begin{array}{l}\text { Chinese (men =136, } \\
\text { women }=132)\end{array}$} & \multicolumn{3}{|c|}{ Significance, $p$ value } \\
\hline & & & & $I v M$ & $I v C$ & $M v C$ \\
\hline \multicolumn{7}{|c|}{ Homocysteine $(>14.0 \mu \mathrm{mol} / \mathrm{l})$} \\
\hline Men & $60.0(51.5,68.5)$ & $53.9(44.4,63.5)$ & $56.6(48.2,64.9)$ & 0.35 & 0.58 & 0.68 \\
\hline Women & $21.9(14.6,29.2)$ & $37.8(28.6,47.1)$ & $30.6(22.7,38.5)$ & $<0.01$ & 0.11 & 0.24 \\
\hline \multicolumn{7}{|c|}{ Folate $(<6.8 \mathrm{nmol} / \mathrm{l})$} \\
\hline Men & $44.9(36.3,53.4)$ & $45.3(35.7,54.9)$ & $31.4(23.6,39.2)$ & 0.95 & 0.02 & 0.03 \\
\hline Women & $36.6(27.9,45.2)$ & $24.5(16.3,32.7)$ & $12.6(6.9,18.3)$ & 0.05 & 0.02 & 0.13 \\
\hline
\end{tabular}


Indians and Malays than Chinese, though there was statistical significance only in women, with differences of $2.9 \mathrm{nmol} / 1$ and 3.0 nmol/1 respectively (table 2). Table 3 shows that Indians had higher proportions with low folate than Chinese by $13.5 \%$ in men and $24.0 \%$ in women and Malays had higher proportions than Chinese by $13.9 \%$ in men and $11.9 \%$ in women. There was no difference for the proportion with low folate between Indians and Malays in men, but in women Indians had a higher proportion than Malays by $12.1 \%$.

Table 2 shows that mean plasma vitamin B12 concentrations (which showed no important gender differences) were lower in Indians and Chinese than Malays for both genders. For men, vitamin B12 was lower in Indians by $78.0 \mathrm{pmol} / 1$ and in Chinese by $59.4 \mathrm{pmol} / 1$, while for women the differences were 135.3 $\mathrm{pmol} / \mathrm{l}$ and $112.3 \mathrm{pmol} / \mathrm{l}$ respectively. Indians had lower levels than Chinese for both genders but the differences were not statistically significant.

\section{Discussion}

The subjects were fasting as recommended for homocysteine measurement. ${ }^{14}$ For all three ethnic groups, plasma levels of total homocysteine were higher in men than women (as in other studies, $\left.{ }^{11}\right)$, those of folate were higher in women than men, while there were no gender differences for vitamin B12. Plasma levels of folate and vitamin B12 were directly correlated, as their metabolism is linked. Folate was inversely correlated with homocysteine, but there was no correlation between vitamin B12 and homocysteine. Other studies have found that homocysteine is most strongly correlated with folate. ${ }^{14}$

Indians and Malays had lower mean plasma folate and a higher proportion with low levels than Chinese. Folic acid is present in most foods, particularly organ meats (especially liver), fresh green vegetables, and some fresh fruits. ${ }^{15}$ Folate is heat labile and largely destroyed by prolonged cooking. ${ }^{15}$ Vitamin $\mathrm{C}$ is similarly destroyed and diets low in vitamin $\mathrm{C}$ are low in folate. ${ }^{15}$ Interestingly, plasma vitamin $\mathrm{C}$ has also been found to be lower in Indians and Malays than Chinese in Singapore. ${ }^{5}$ There is more prolonged cooking at high temperatures with Indian and Malay dishes such as curries compared with the typical Chinese stir fried dishes, with probably more destruction of dietary folate and vitamin C. Lower folate levels in Indians and Pakistanis than in white populations has been found in the United Kingdom and this has been attributed to their diet. ${ }^{16}$ Overall, a high proportion of people in Singapore have low folate levels, which has been found in other populations. ${ }^{13}$

Mean plasma vitamin B12 was lowest in Indians, then Chinese, and then Malays, for both genders, though the differences between Indians and Chinese were not statistically significant. Vitamin B12 is mainly present in animal protein particularly organ meats (especially liver) and bivalves (clams and oysters), and to a less extent in seafood, milk and milk products. ${ }^{15}$ Vitamin B12 is resistant to heat, ${ }^{15}$ though deficiency may occur in vegetarians, in whom small amounts in legumes may be the only dietary source. ${ }^{15}$ Lower plasma vitamin $\mathrm{B} 12$ in Indians is probably explained by their more vegetarian diet; as found in a food consumption survey. ${ }^{17}$

Lower levels of folate and vitamin B12, together with lower levels of vitamin C and selenium as previously reported, ${ }^{5}$ indicates lower anti-oxidant activity in Indians, which may play a part in their higher susceptibility to CHD.

However, there are no ethnic differences for plasma homocysteine. The small ethnic differences in folate and vitamin B12 are not translated into different homocysteine levels. In Singapore, hyperhomocysteinaemia does not seem to be part of the explanation for ethnic differences in CHD and in particular the increased susceptibility of Indians to the disease.

Bangladeshis have been found to have higher homocysteine levels than the white population in the United Kingdom and this has been put forward as a possible explanation for their higher rates of CHD. ${ }^{18}$ This study in Singapore does not support this, in so far as Indians have more CHD than Malays and Chinese despite similar levels of homocysteine.

However, it should be noted that levels of plasma homocysteine for all three ethnic groups in Singapore are higher than have been reported in the West. A study is in progress to determine the frequencies of methylenetetrahydrofolate reductase (MTHFR) genotypes as a possible explanation for these high levels. MTHFR is an enzyme in the metabolism of homocysteine and its genotypes are associated with different levels of homocysteine. ${ }^{19}$

We are grateful to Ms BL Lee and Ms V Ng for technical assistance.

Funding: the National University of Singapore Heart Study was funded by the National University of Singapore and the National Medical Research Council. Laboratory measurements were financed by the Centre for Environmental and Occupational Health Research.

Conflicts of interest: none.

1 McKeigue PM. Coronary heart disease in Indians, Pakistanis, and Bangladeshis: aetiology and possibilities for prevention. Br Heart f 1992;67:341-2.

2 Hughes K, Lun KC, Yeo PBB. Cardiovascular diseases in Chinese, Malays, and Indians in Singapore. I. Differences in mortality. F Epidemiol Community Health 1990;44:24-8. in mortality. F Epidemiol Community Health 1990;44:24-8. Hughes K, Yeo PBB, Lun KC, et al. Cardiovascular diseases in Chinese, Malays, and Indians in Singapore. II. Differences in risk factor $1990 ; 44: 29-35$.

4 Hughes K, Aw TC, Kuperan P, et al. Central obesity, insulin Hughes K, Aw TC, Kuperan P, et al. Central obesity, insulin
resistance, syndrome X, lipoprotein(a), and cardiovascular resistance, syndrome X, lipoprotein(a), and cardiovascular
risk in Indians, Malays and Chinese in Singapore. $\mathcal{F}$ Epiderisk in Indians, Malays and Chinese in Sin
miol Community Health 1997;51:394-9.

5 Hughes K, Ong CN. Vitamins, selenium, iron, and coronary heart disease risk in Indians, Malays and Chinese in Singapore. F Epidemiol Community Health 1998;52:181-5.

6 Welch GN, Loscalzo J. Mechanisms of disease: homocysteine and atherothrombosis (review article). N Engl f Med 1998;338:1042-50.

7 Ford ES, Byers TE, Giles WH. Serum folate and chronic disease risk: findings from a cohort of United States adults. Int $\mathcal{F}$ Epidemiol 1998;27:592-8.

8 Boushey CJ, Beresford SA, Omenn GS, et al. A quantitative assessment of plasma homocysteine as a risk factor for vascular disease: probable benefits of increasing folic acid cular disease: probable benefits

9 Smolin LA, Schneider JA. Measurement of total plasma cysteamine using high-performance liquid chromatography with electrochemical detection. Anal Biochem 1988;168: with electi $374-9$. 
10 Fenech M, Aitken C, Rinaldi J. Folate, vitamin $B_{12}$ homocysteine status and DNA damage in young Australian homocysteine status and DNA damage in
adults. Carcinogenesis 1998;19:1163-71.

11 Ueland PM, Refsum H, Brattstrom L. Plasma homocysteine and cardiovascular disease. In: Francis RB Jr, ed. Atherosclerotic cardiovascular disease, hemostasis, and endothelial function. New York: Dekker, 1992:183-236.

12 Selhub J, Jacques PF, Wilson PW, et al. Vitamin status and intake as primary determinants of homocysteinemia in an elderly population. fAMA 1993;270:2693-8.

13 Blount BC, Mack MM, Wehr CM, et al. Folate deficiency causes uracil misincorporation into human DNA and chromosome breakage: implications for cancer and neuronal damage. Proc Natl Acad Sci USA 1997;94:3290-5.

14 Miner SE, Evrovski J, Cole DE. Clinical chemistry and molecular biology of homocysteine metabolism: An update. Clin Biochem 1997;30:189-201
15 Herbert V, Das KC. Folic acid and vitamin $\mathrm{B}_{12}$. In: Shils ME, Olson JA, Shike M, eds. Modern nutrition in health and disease. 8th ed. Philadelphia: Lea \& Febiger, 1994:402-25.

16 Michie CA, Chambers J, Abramsky L, et al. Folate deficiency, neural tube defects, and cardiac disease in UK Indians and Pakistanis. Lancet 1998;351:1105.

17 Food and Nutrition Department. Food consumption study 1993. Singapore Ministry of Health, April 1994.

18 Obeid OA, Mannan N, Perry G, et al. Homocysteine and folate in healthy east London Bangladeshis. Lancet 1998;352:1829-30.

19 Motti C, Gnasso A, Bernardini S, et al. Common mutation in methylenetetrahydrofolate reductase. Correlation with homocysteine and other risk factors for vascular disease. Atherosclerosis 1998;139:377-83. 